\title{
THE EFFECT OF INTERFERON- $\gamma$ AND LIPOPOLYSACCHARIDE ON THE GROWTH OF FRANCISELLA TULARENSIS LVS IN MURINE MACROPHAGE-LIKE CELL LINE J774
}

\author{
Monika Holická, Jakub Novosad, Martina Loudová, Manuela Kudlová, Jan Krejsek
}

Charles University in Prague, Faculty of Medicine and University Hospital Hradec Králové, Czech Republic: Department of Clinical Immunology and Allergology

\begin{abstract}
Summary: Background: Francisella tularensis, a causative agent of human tularemia, displaying the ability to proliferate inside the human cells. Aims: To evaluate the growth potential of F. tularensis LVS strain in macrophage-like cell line J774 modulated by recombinant interferon $\gamma$ and $E$. coli derived lipopolysaccharide. Results: Stimulation of J774 cells either by interferon- $\gamma$ or lipopolysaccharide alone, or especially in combination before infection $F$. tularensis, revealed protective effects. Higher concentrations of stimulating agents were needed to inhibit ongoing $F$. tularensis infection. Conclusions: Stimulation of $\mathbf{J} 774$ cell line by combination of interferon- $\gamma$ with lipopolysaccharide inhibits the intracellular growth of $F$. tularensis.
\end{abstract}

Key words: Francisella tularensis; Macrophage; Interferon- $\gamma ;$ Lipopolysaccharide

\section{Introduction}

Francisella tularensis is a Gram-negative facultative intracellular bacterium and the causative agent of tularemia (12, $14)$, a severe and often fatal disease of human and other mammals (5). F. tularensis subspecies tularensis is highly infectious, with intradermal or inhalation routes of infections requiring only about 10 organisms to cause severe disease (4). The fact that only a few organisms at cutaneous or mucosal sites can cause overwhelming disease suggests that the organism is able to overcome innate immune clearance efficiently. Because of the practical and regulatory complications of work with fully virulent clinical isolates, most of the available studies of an early host response to $F$. tularensis have used the live vaccine strain (LVS), which is attenuated for humans but causes a fatal infection in mice (2). F. tularensis replicates in macrophages and macrophage-related cells (12). Growth inside macrophages is a strategy that many prokaryotic and eukaryotic pathogens use to evade the host immune responses. Growth inside macrophages not only protects microbes during the acute phase of disease but also serves as niche for the long-term survival of pathogens (6). Current opinion is that $F$. tularensis is able to escape from the phagosomes of macrophages via a mechanism that may involve degradation of phagosomal membrane (9). Santic et al. (16) found that entry of $F$. tularensis into macrophages is mediated by novel asymmetric, spacious pseudopod loops, and the nascent phagosome becomes tight fitting within seconds of formation. Biogenesis of the Francisellacontaining phagosome (FCP) is arrested for $2-4 \mathrm{hrs}$ at a unique stage within endosomal-lysosomal degradation pathway, followed by gradual bacteria escape into cytosol, where the microbes are proliferating.

Based on in vitro data and in vivo observations made in both animals and humans, one specific cytokine, interferon gamma (IFN- $\gamma$ ), appears to play a key role in activating of mononuclear phagocytes (15). IFN- $\gamma$ is known to be the most potent activator of macrophages inducing both antimicrobicidal and antitumor mechanisms as well as up-regulating antigen processing and presentation pathways (17). LPS, bacterial lipoproteins (18) and other pathogen-associated molecular patterns (PAMPs) (17) are activating Tolllike receptors (TLR) of mononuclear phagocytes, thereby inducing proinflammatory cytokines and antimicrobial activity (18) in macrophages.

We examined the abilities of the recombinant murine lymphokine INF- $\gamma$ and/or LPS derived from E. coli to stimulate in vitro antimicrobial activity of macrophage-like J774 cell line against the live vaccine strain (LVS) of Francisella tularensis through the abilities of activated macrophages to reduce proliferation of this bacteria. In addition, we followed dose-dependent influences of these stimulants on intracellular proliferation of $F$. tularensis and putative effect of pretreatment of J774 cells either by INF- $\gamma$ or LPS alone or in combination.

\section{Materials and methods \\ In vitro infection of $\mathrm{J} 774$ cells}

Conditions of infection were selected to ensure the multiplicity of infection (MOI) (i.e., ratio of bacterial cells to 
J774 cells) to be 200 . J774 cells derived from female BALB/c mouse (ECACC, No: 85011428) were cultured for $48 \mathrm{hrs}$ in a complete culture medium without gentamicin. Francisella tularensis LVS strain (ATCC 29684, American Type Culture Collection, Manassas, Va.) was cultured on McLeod agar plates for $48 \mathrm{hrs}$ at $37^{\circ} \mathrm{C}$ in atmosphere containing $5 \% \mathrm{CO}_{2} . \mathrm{J} 774$ cells were exposed to LVS strain for $2 \mathrm{hrs}$ at $37^{\circ} \mathrm{C}$ in culture medium without gentamicin. Infected cells were than cultivated in culture medium supplemented with gentamicin for $1 \mathrm{hrs}$ at $37{ }^{\circ} \mathrm{C}$ in atmosphere containing $5 \%$ $\mathrm{CO}_{2}$ and then washed three times with culture medium without gentamicin. Infected macrophages were incubated in 6 -well cultivation platelets $\left(2 \times 10^{6}\right.$ cells per $4 \mathrm{ml}$ of medium Dulbecco's MEM with Glutamax-1 with 10\% BSA, Gibco $\left.^{\mathrm{TM}}\right)$. This was the time point 0 .

\section{Proliferation of Francisella tularensis, viability and number of cells}

To determine the number of intracellular bacteria, cells were washed once in PBS and suspended in $1 \mathrm{ml}$ of PBS $100-\mu 1$ portions of each sample, serially diluted in PBS, were cultured on McLeod agar plates. The number of cells and viability were calculated using trypan blue exclusion test $(0.5 \%$ TB in saline). Samples were collected each $3 \mathrm{hrs}$ during $12 \mathrm{hrs}$ of cultivation of cells and than after $24 \mathrm{hrs}$.

\section{Stimulation of macrophage-like $\mathbf{J 7 7 4}$ cells}

Recombinant murine interferon $\gamma$ (mouse recombinant, expressed in E. coli, SIGMA, Saint Louis, Missouri, USA), in concentrations 100 I.U. per $1 \mathrm{ml}$ or 1000 I.U. per $1 \mathrm{ml}$ of medium, and/or bacterial lipopolysaccharide derived from $E$. coli (from E. coli serotype O55:B5, SIGMA, Saint Louis, Missouri, USA), in concentration $10 \mathrm{ng}$ per $1 \mathrm{ml}$ of medium or $50 \mathrm{ng}$ per $1 \mathrm{ml}$ of medium, was used for stimulation immediately after infection (at the time 0 ) or $3 \mathrm{hrs}$ before infection.

\section{Statistical analysis}

Results expressed as mean \pm S.D. were derived from three independent experiments. Analysis of variance followed by Scheffe's evaluation of contrasts was exploited to reveal significant differences.

\section{Results}

\section{Infection of $\mathbf{J} 774$ macrophages by $F$. tularensis with subsequent stimulation by INF- $\gamma$ or/and LPS}

In the first experiment, macrophage-like J774 cells were treated with 100 or $1000 \mathrm{IU} / \mathrm{ml}$ of INF- $\gamma$ and/or 10 or 50 $\mathrm{ng} / \mathrm{ml}$ of LPS that was added into infected cell cultures at the time 0. The growth of Francisella tularensis LVS was monitored in the course of $12 \mathrm{hrs}$, each $3 \mathrm{hrs}$ and at the time 24 and 48 hrs (event. 72 hrs) thereafter.
Concentrations $1000 \mathrm{IU} / \mathrm{ml}$ of INF- $\gamma$ (Fig. 1) effectively suppressed $(\mathrm{p}<0.01)$ growth of Francisella tularensis LVS at the time $48 \mathrm{hrs}$ and $72 \mathrm{hrs}$ (data not shown) of cultivation of infected cells. The bacterial counts were decreased by approximately $2 \log 10$. This effect was not observed in the case of concentration $100 \mathrm{IU} / \mathrm{ml}$ of INF- $\gamma$. Furthermore, the proliferation of $F$. tularensis in $\mathrm{J} 774$ cell treated by $1000 \mathrm{IU} / \mathrm{ml} \mathrm{INF-} \gamma$ was significantly lower $(\mathrm{p}<0.01)$ compared to cell cultures stimulated by $100 \mathrm{IU} / \mathrm{ml} \mathrm{INF}-\gamma$ at the 48 hrs of cultivation. Treatment of macrophages with LPS (Fig. 2) displayed only a little effect on the growth of $F$. $t u$ larensis LVS with the only exception at the time $48 \mathrm{hrs}$, when concentration $50 \mathrm{ng} / \mathrm{ml}$ of LPS slightly suppressed proliferation of $F$. tularensis LVS ( $<<0.05)$. This effect was not observed at 72 hrs of cultivation of cells (data not shown).

Conversely, combination of INF- $\gamma$ and LPS (Fig. 3) was remarkable effective. This effect was observed after $24 \mathrm{hrs}$ of cultivation of macrophages. Proliferation of $F$. tularensis LVS was suppressed by both combinations of stimulants ( $100 \mathrm{IU} / \mathrm{ml}$ of INF- $\gamma+10 \mathrm{ng} / \mathrm{ml}$ of LPS and $1000 \mathrm{IU} / \mathrm{ml}$ of INF- $\gamma+50 \mathrm{ng} / \mathrm{ml}$ of LPS $)(\mathrm{p}<0.01)$ in comparison with cells infected by F. tularensis only. At the time of $48 \mathrm{hrs}$, the combination of higher doses suppressed growth of bacteria more effectively compared to combination of lower doses of stimulants $(\mathrm{p}<0.01)$. At the time $48 \mathrm{hrs}$ of cultivation of infected cells the number of $F$. tularensis decreased approximately $4 \log 10$ in comparison with infected cells only.

No direct effect of stimulants on the viability and number of $\mathbf{J} 774$ cells in the entire course of cultivations of cells was observed (data not shown). However, higher doses of INF- $\gamma$ only or in combination with higher doses of LPS reduced the number of cells at $24 \mathrm{hrs}$ and $48 \mathrm{hrs}$ of cultivation of macrophage-like $\mathrm{J} 774$ cell line.

\section{Stimulation of J774 macrophages by INF-yor/and LPS with subsequent infection by $F$. tularensis}

In these experiments, macrophage-like $\mathrm{J} 774$ cells were treated $3 \mathrm{hrs}$ before infection with 100 or $1000 \mathrm{IU} / \mathrm{ml}$ of rINF- $\gamma$ and/or 10 or $50 \mathrm{ng} / \mathrm{ml}$ of LPS. Macrophage-like J774 cells were washed after stimulation and infected with F. tularensis LVS. The ability of INF- $\gamma$ and LPS to activate macrophages and inhibit the replication of $F$. tularensis LVS was monitored at the same time as stimulation of infected cells.

The number of bacteria at $48 \mathrm{hrs}$ of cultivation of cells in the presence $1000 \mathrm{IU} / \mathrm{ml}$ of INF- $\gamma$ (Fig. 4) was decreased in comparison with control (only infected cells) $(\mathrm{p}<0.05)$. At that time the bacterial number decreased approximately $2 \log 10$.

Treatment of macrophages with LPS alone (Fig. 5) had no effect on the growth of $F$. tularensis, but this effect was monitored through $24 \mathrm{hrs}$ of cultivation only.

The effect of combinations of $100 \mathrm{IU} / \mathrm{ml}$ of INF- $\gamma$ with $10 \mathrm{ng} / \mathrm{ml}$ of LPS and $1000 \mathrm{IU} / \mathrm{ml}$ of INF- $\gamma$ with $50 \mathrm{ng} / \mathrm{ml}$ of LPS (Fig. 6) on the growth of $F$. tularensis LVS were signi- 

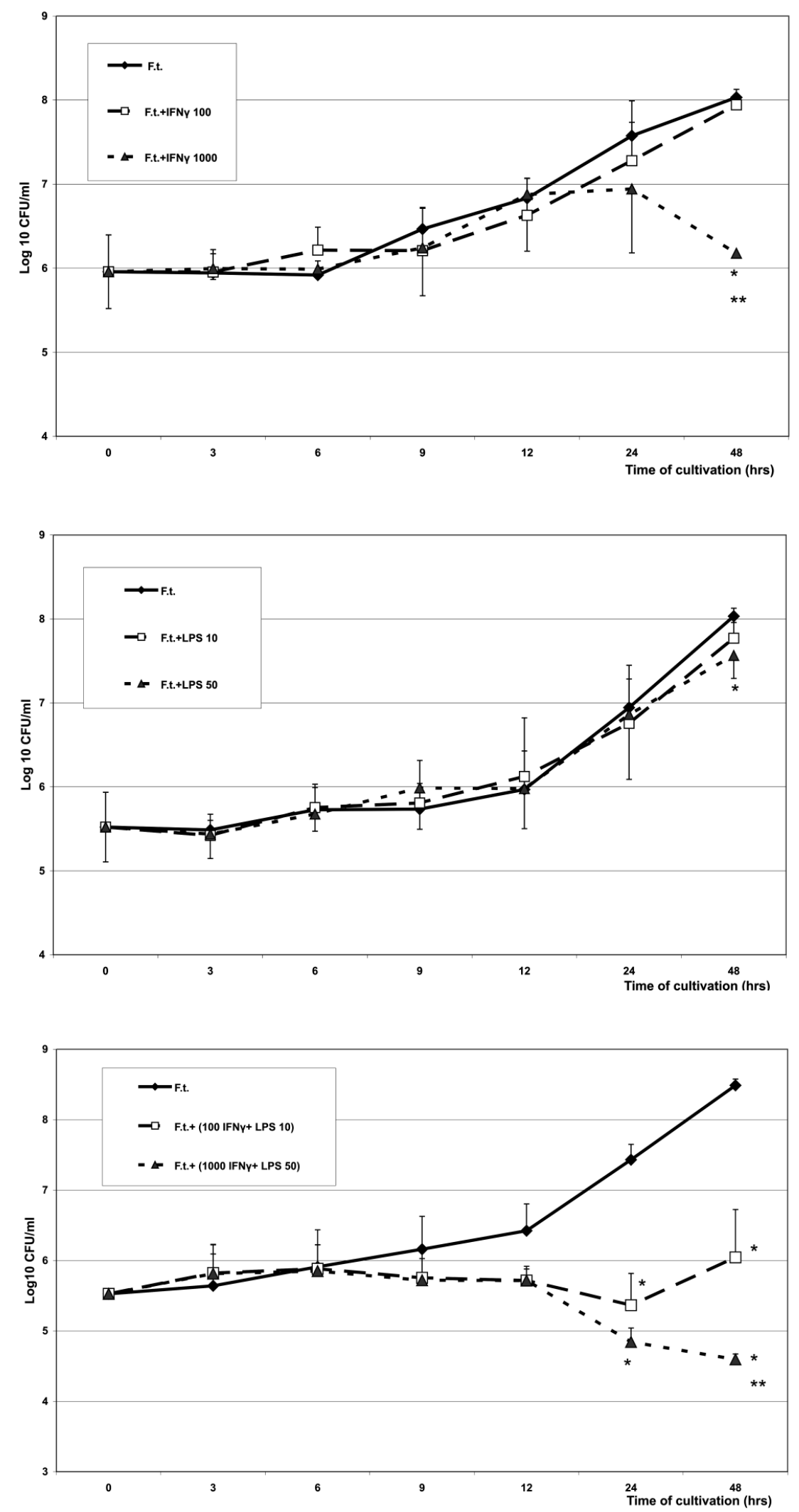

Fig. 1: Proliferation of $F$. tularensis LVS in macrophage-like cell line $\mathbf{J} 774$. The infection of cells by $F$. tularensis LVS with subsequent stimulation by $100 \mathrm{IU} / \mathrm{ml}$ of IFN $\gamma$ or $1000 \mathrm{IU} / \mathrm{ml}$ of IFN $\gamma .{ }^{*} \mathrm{p}<0.01$ compared with infection by $F$. tularensis only, ${ }^{* *} \mathrm{p}<0.01$ compared with infection by $F$. tularensis with consequential stimulation by 100 $\mathrm{IU} / \mathrm{ml}$ of IFN $\gamma$.

Fig. 2: Proliferation of $F$. tularensis LVS in macrophage-like cell line J774. The infected cells were subsequently stimulated by $10 \mathrm{ng} / \mathrm{ml}$ of LPS or 50 $\mathrm{ng} / \mathrm{ml}$ of LPS. * $\mathrm{p}<0.05$ compared with infection by $F$. tularensis only.

Fig. 3: Proliferation of $F$. tularensis LVS in macrophage-like cell line J774. The infection of cells by $F$. tularensis with subsequent stimulation by combination of $100 \mathrm{IU} / \mathrm{ml}$ of IFN $\gamma$ with 10 $\mathrm{ng} / \mathrm{ml}$ of LPS or $1000 \mathrm{IU} / \mathrm{ml}$ of IFN $\gamma$ with $50 \mathrm{ng} / \mathrm{ml}$ of LPS. * $\mathrm{p}<0.01$ compared with infection by $F$. tularensis only, $* * \mathrm{p}<0.01$ compared with infection by F. tularensis with consequential stimulation by $100 \mathrm{IU} / \mathrm{ml}$ of IFN $\gamma$ with 10 $\mathrm{ng} / \mathrm{ml}$ of LPS.

Legends: Results expressed as mean \pm S.D. were derived from three independent experiments. 

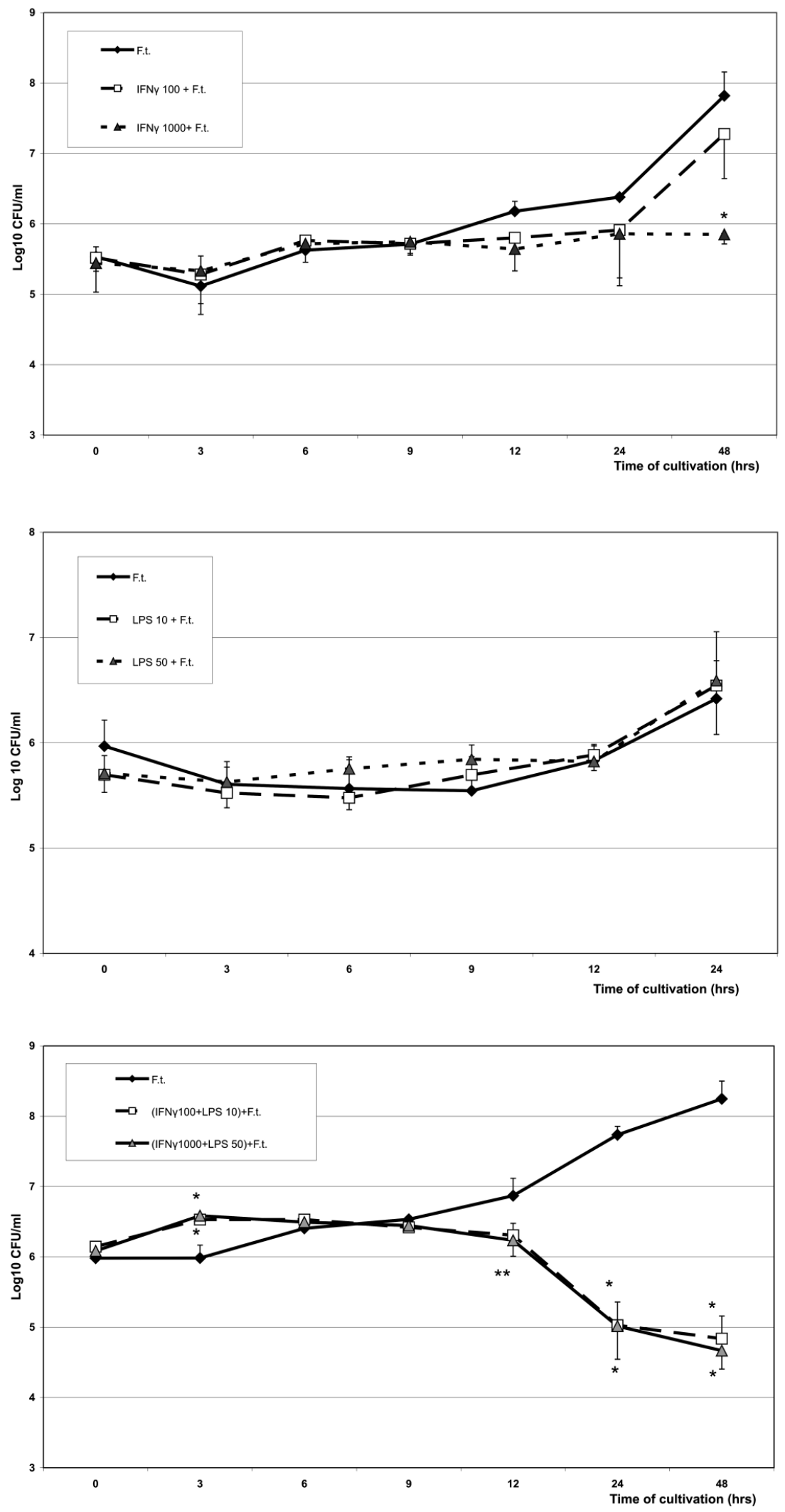

Fig. 4: Proliferation of $F$. tularensis LVS in macrophage-like cell line $\mathbf{J} 774$. The cells were stimulated by 100 $\mathrm{IU} / \mathrm{ml}$ of IFN $\gamma$ or $1000 \mathrm{IU} / \mathrm{ml}$ of IFN $\gamma$ with subsequential infection by $F$. tularensis. ${ }^{*} \mathrm{p}<0.05$ compared with infection by F. tularensis only.

Fig. 5: Proliferation of $F$. tularensis LVS in macrophage-like cell line $\mathbf{J} 774$. The cells were stimulated by $10 \mathrm{ng} / \mathrm{ml}$ of LPS or $50 \mathrm{ng} / \mathrm{ml}$ of LPS with subsequent infection by F. tularensis.

Fig. 6: Proliferation of $F$. tularensis LVS in macrophage-like cell line $\mathbf{J} 774$. The cells were stimulated by combination of $100 \mathrm{IU} / \mathrm{ml}$ of IFN $\gamma$ with 10 $\mathrm{ng} / \mathrm{ml}$ of LPS or $1000 \mathrm{IU} / \mathrm{ml}$ of IFN $\gamma$ with $50 \mathrm{ng} / \mathrm{ml}$ of LPS with subsequent infection by $F$. tularensis. * $\mathrm{p}<0.01 \mathrm{com}$ pared with infection by $F$. tularensis only, ${ }^{* *}$ p $<0.05$ pretreatment by combination of $1000 \mathrm{IU} / \mathrm{ml}$ of IFN $\gamma$ with 50 $\mathrm{ng} / \mathrm{ml}$ of LPS compared with infection by $F$. tularensis only.

Legends: Results expressed as mean \pm S.D. were derived from three independent experiments. 
ficant. The accumulation of bacteria inside the cells was observed after $3 \mathrm{hrs}$ of cultivation of macrophages. This effect was observed in the case of both lower and higher combination of stimulants $(\mathrm{p}<0.01)$. This effect was not dose dependent. Down regulation of growth of $F$. tularensis LVS was observed after $12 \mathrm{hrs}$ of cultivation of cells. Only higher combination of stimulants suppressed proliferation of bacteria in comparison with the only infected control $(p<0.05)$. The strong effect on growth of $F$. tularensis was observed after 24 hrs of cultivation of macrophages, when bacterial number decreased by $3 \log 10$. This effect was not dose dependent.

We found a negative influence of combination of stimulants on the viability of macrophage cells (data not shown). Cell viability was decreased at the time 9 hrs of cultivation; $100 \mathrm{IU} / \mathrm{ml}$ of INF- $\gamma+10 \mathrm{ng} / \mathrm{ml}$ of LPS ( $\mathrm{p}<0.01$ ) or $1000 \mathrm{IU} / \mathrm{ml}$ of INF- $\gamma+50 \mathrm{ng} / \mathrm{ml}$ of LPS $(\mathrm{p}<0.01)$, compared with infection by $F$. tularensis only. On the other hand, cell viability was increased at $48 \mathrm{hrs}$ of cultivation; $100 \mathrm{IU} / \mathrm{ml}$ of INF- $\gamma+10 \mathrm{ng} / \mathrm{ml}$ of LPS $(\mathrm{p}<0.01)$, or $1000 \mathrm{IU} / \mathrm{ml}$ of INF- $\gamma+50 \mathrm{ng} / \mathrm{ml}$ of LPS $(\mathrm{p}<0.05)$, compared with infection by $F$. tularensis only.

\section{Discussion}

Macrophage is an important effector cell for both cellular and humoral immunity. Pathogens have complex strategies for intracellular survival in these cells. These strategies are as diverse as the microorganisms themselves (8). Little is know about the means $F$. tularensis bacteria survive within host cells, since, unlike many other facultative intracellular bacteria, it produces no toxins and no secretion systems (13). Lai et al. have shown that LVS strain is well adapted to the intracellular environment of macrophages. Recently, it has been shown that $F$. tularensis is capable to escape effectively from phagosomes of macrophages $(9,16)$. The ability of $F$. tularensis to survive and multiply in various cell types is well recognized $(1,3,5,8,10)$. In agreement with results of previous studies, we found a rapid multiplication of F. tularensis in untreated cultures of J774 line after $12 \mathrm{hrs}$ of infection with comparison to the works by Lai et al. (13) and Hrstka et al. (11). However, compared to Lai et al. who revealed $2 \log 10$ increase in the member of viable $F$. tularensis bacteria in the 12 to $24 \mathrm{hrs}$ of cultivation we found only $1 \log 10$ increase. However, our results are apparently in the concordance as MOI used by us was the half only. Similar results were also obtained in the case of resident peritoneal macrophages (8). INF- $\gamma$ is particularly important to host defence, exspecially early in the response to primary infection, perhaps through their ability to activate macrophages for more efficient killing of $F$. tularensis $(1,2,8)$. Similarly, LPS activates Toll-like receptors of mononuclear phagocytes, thereby inducing proinflammatory cytokines and antimicrobial activity (18). We only found the positive effect of INF- $\gamma$ on the reduction of $F$. tularensis if infected cells were exposed to the higher concentration of INF- $\gamma$ for 48 hrs of cultivation irrespective to the stimulants used.
The effect of the stimulation of J774 cells by LPS was very limited, if any. Telepnev et al. (18) published that $F$. $t u$ larensis is capable in macrophage-like cell line J774 of suppressing the capability of the cells to respond to LPS or bacterial lipopeptide. It could be the reason for the fact that J774 cells stimulated by LPS are not capable to supports the growth of $F$. tularensis. Rather different results were obtained if $\mathrm{J} 774$ cells were either pretreated or treated with the combination of INF- $\gamma$ with LPS. This combination significantly suppressed the proliferation of $F$. tularensis in both pretreated and treated cells. If we stimulated the cells after infection by combination of stimulatory agents, a dose dependent effect was evident. Growth suppression of $F$. tularensis was prolonged up to $48 \mathrm{hrs}$ of cultivation only if higher concentrations of stimulatory agents were used. On the other hand, the F. tularensis growth at 3 hrs after infection was significantly stimulated by the pretreatment by INF- $\gamma$ with LPS irrespective concentrations used compared to untreated cell only. At that time J774 cells have already been exposed to the stimulation for $9 \mathrm{hrs}$. One plausible explanation of this fact could be better internalisation of $F$. tularensis by pretreated cells. This phenomenon was not identified at the any other points of observation. In contrast, we found decreased counts of $F$. tularensis at those intervals. Similar decreases were achieved if infected J774 cells were subsequently stimulated. The significant decrease in the number of $F$. tularensis was apparent after stimulation by $1000 \mathrm{IU} / \mathrm{ml}$ of INF- $\gamma$ and $50 \mathrm{ng} / \mathrm{ml}$ of LPS before the start of infection already after $12 \mathrm{hrs}$ of cultivation compared with the cells treated after infection. The multiplication of $F$. tularensis in pretreated $\mathbf{J} 774$ cells was significantly diminished after $24 \mathrm{hrs}$ of cultivation being similar in both concentrations of INF- $\gamma$ with LPS.

The most important limitation of our study is the fact that $E$. coli LPS was used to stimulate $\mathrm{J} 774$ cells. There are substantial differencies in the capacity of LPSs isolated from different bacterial species or even from various strains of the same species to stimulate host response. This has been recently addressed by Duenas et al. (7) who found much lower potency of $F$. tularensis LPS to stimulate human monocytes via TLR4 compared to E. coli LPS.

To summarize, it is apparent from our results that INF- $\gamma$ alone has a protective effect regarding $F$. tularensis infection of macrophage-like J774 cells. This effect was even more pronounced if cells were treated by the combination of INF- $\gamma$ with LPS. If cells were stimulated before infection by F. tularensis LVS, lower concentrations of INF- $\gamma$ (tenfold) and LPS (fivefold), respectively, were sufficient to diminish the proliferation of F. tularensis LVS. If the infection of J774 macrophages by $F$. tularensis has already been in progress, higher concentrations of INF- $\gamma$ and LPS were necessary to suppress the growth of $F$. tularensis in macrophage-like $\mathrm{J} 774$ cell line.

\section{Acknowledgments}

The presented study was fully supported by Ministry of Education, Youth and Sport, Czech Republic, grant 
No. LN00A033. We thank Mrs. Hana Kotlandová for her assistance.

\section{References}

1. Anthony LS, Ghadirian E, Nestel FP, Kongshavn PA. The requirement for gam ma interferon of mice to experimental tularemia. Microbial Pathog 1989;7:421-8.

2. Barker JH, Weiss J, Apicella M, Nauseef WM. Basis for the failure of Francisella tularensis lipopolysaccharide to prime human polymorphonuclear leukocytes. Infect Immunity 2006; 74:3277-84.

3. Bosio CM, Elkins KL. Susceptibility to secondary Francisella tularensis live vaccine strain infection in B-cell-deficient mice is associated with neutrophilia but not with defects in specific T-cell-mediated immunity. Infect Immun 2001; 69:194-203.

4. Carlson Jr PE, Carrol JA, O’Dee DM, Nau GJ. Modulation of virulence factors in Francisella tularensis determines human macrophage response. Microbial Pathogen 2007;42:204-14

5. Chen W, KuoLee R, Shen H, Busa M, Conlan JW. Toll-like receptor 4 (TLR4) plays a relatively minor role in murine defense against primary intradermal infection with Francisella tularensis LVS. Immunol Lett 2005;97:151-4.

6. Cowley SC, Myltseva SV, Nano FE. Phase variation in Francisella tularensis af fecting intracellular growth, lipopolysaccharide antigenicity and nitric oxide production. Mol Microbiol 1996;20:867-74.

7. Duenas AI, Aceves M, Orduna A, Diaz R, Sanchez Crespo M, Garcia-Rodriguez C. Francisella tularensis LPS induces the production of cytokines in human monocytes and signals via Toll-like receptor 4 with much lower potency than E. coli LPS. Int Immunol 2006;18(5):785-95.

8. Fortier AH, Polsinelli T, Green SJ, Nacy CA. Activation of macrophages for de- struction of Francisella tularensis: Identification of cytokines, effector cells, and effector molecules. Infect Immun 1992;60:817-25.

9. Golovliov I, Baranov V, Krocova Z, Kovarova H, Sjöstedt A. An attenuated strain of the facultative intracellular bacterium Francisella tularensis can escape the phagosome of monocytic cells. Infect Immun 2003;71(10):5940-50

10. Golovliov I, Sandström G, Ericsson M, Sjöstedt A, Tärnvik A. Cytokine expression in the liver during the early phase of murine tularemia. Infect Immun 1995;63:534-8

11. Hrstka R, Stulik J, Vojtesek B. The role of MAPK signalling pathway during Fran cisella tularensis LVS infection-induced apoptosis in murine macrophages. Microbe Infect 2005;7(4):619-25.

12. Kieffer TL, Cowley S, Nano FE, Elkins KL. Francisella novicida LPS has immunobiological activity in mice than F. tularensis LPS, and contributes to $F$. novicida murine pathogenesis. Microbes Infect 2003;5(5):397-403.

13. Lai XH, Golovliov I, Sjöstedt A. Francisellla tularensis induced cytopathogenicity and apoptosis in murine macrophages via a mechanism that requires intracellular bacterial multiplication. Infect Immun 2001;69:4691-4

14. Li H, Nookala S, Bina XR, Bina JE, Re F. Innate immune response to Francisella tularensis is mediated by TLR2 and caspase-1 activation. J Leukoc Biol 2006;80 766-73

15. Murray HW. Gamma interferon, cytokine-induced macrophage activation, and antimicrobial host defence. Diag Microbiol Infect Dis 1990;13:411-21.

16. Santic M, Molmeret M, Klose KE, Kwaik YA. Francisella tularensis travels, a novel, twisted road within macrophages. Trends Microbiol 2006;14:37-44.

17. Schroder K, Hertzog PJ, Ravasi T, Hume DA. Interferon- $\gamma$ : an overview of signals, mechanisms and functions. J Leuk Biol 2004;75:163-89.

18. Telepnev M, Golovliov I, Grundström T, Tärnvik A, Sjöstedt A. Francisella tula rensis inhibits Toll-like receptor-mediated activation of intracellular signalling and secretion of TNF- $\alpha$ and IL-1 from murine macrophages. Cell Microbiol 2003; $5(1): 41-51$.

Received: $31 / 07 / 2009$.

Accepted: 25/09/2009.

\section{Corresponding author:}

Prof. RNDr. Jan Krejsek, CSc., Charles University in Prague, University Hospital Hradec Králové, Department of Clinical Immunology and Allergology, Sokolská 581, 50005 Hradec Králové, Czech Republic; e-mail: krejsek@fnhk.cz 